\title{
$1 \quad$ Growing with the Wind: The Case of Vestas
}

Rolf Wüstenhagen, Good Energies Chair for Management of Renewable Energies, University of St. Gallen

\section{Wind Power: Vestas' Fortunes Hinge on the U.S. Wind Market}

Everybody's waiting with baited breath to see how the U.S. wind-power sector develops this year, but few more so than Vestas, the world's biggest wind-turbine maker and a sector bellwether. Vestas, which just reported its best-ever sales and profit numbers, is hedging its optimistic 2009 outlook based on what happens in the U.S., which is by far Vestas' biggest market. The company expects a 19\% jump in sales this year to 7.2 billion euros - but only if wind orders pick up substantially in the first quarter.

"We feel more certain other markets will do their part...where in the U.S. the jury is still out," Vestas chief executive Ditlev Engel told Dow Jones Newswires. If the wind market doesn't recover from the near-total "collapse" in the fourth quarter, Vestas said, the company will rethink its planned 1.2 billion euros in capital spending this year, including expanding three U.S. factories. If orders don't pick up globally, Vestas warned it would have to "seriously consider" layoff. (...)

The U.S. renewable-energy sector, led by wind, is grappling with the fallout of the credit crunch, which has choked off financing for many new projects, even as clean energy enjoys growing political support. "The political climate has never been better, while the financial climate has never been worse," Mr. Engel said at the earnings presentation. (...)

Wall Street Journal, February 12, 2009

\subsection{The Wind Energy Industry - Leading the Transition to a New Energy Economy}

Countries around the world have increasingly become aware of the challenges of climate change and global warming. The Intergovernmental Panel on Climate Change (IPCC) has provided clear scientific evidence that the concentration of greenhouse gases such as carbon dioxide (CO2) is much higher today than ever before in the last 600,000 years (see Exhibit 1.1). As a conclusion, IPCC estimates that the level of global CO2-emissions needs to be reduced by $80 \%$ before 2050 in order to avoid dangerous changes in the earth's atmosphere. Burning fossil fuels such as coal, oil and natural gas for power generation, heating and 
transportation is the most important source of manmade greenhouse gas emissions. More than $80 \%$ of the world's energy supply comes from non-renewable sources, and about $66 \%$ of global oil reserves are found in a small number of countries around the Persian Gulf.

\section{Exhibit 1.1 650’000 year GHG concentration and temperature}

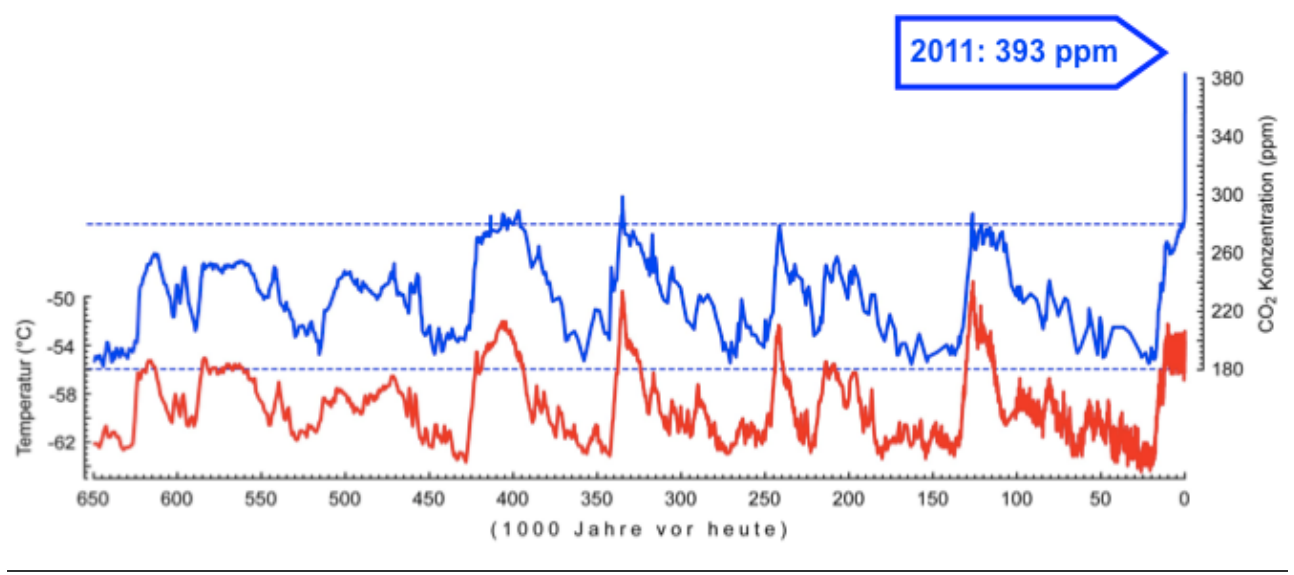

Source: adapted from IPCC (2007)

An important option to curb greenhouse gas emissions, while at the same time decreasing energy import dependence, is to use renewable sources of energy such as electricity generated from sun, wind and water (IPCC 2011). Among those technologies, wind energy has recently experienced the most significant growth and now is the most widely used form of renewable energy worldwide. The global wind energy market has grown with an average $29 \%$ p.a. worldwide over the past two decades (Exhibit 1.2). Initial growth has been facilitated by favorable energy policies in countries like Denmark, Germany and Spain. 


\section{Exhibit 1.2 Historical Growth in Worldwide Wind Energy Capacity 1990-2010}

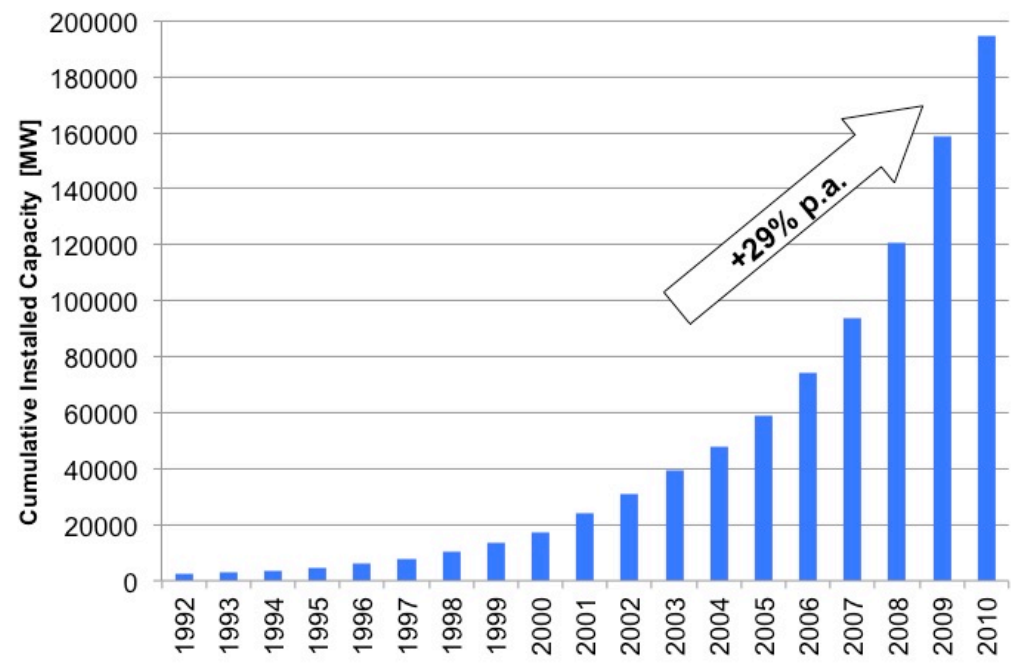

Source: GWEC (2011)

More recently, while still enjoying political support, wind energy is also increasingly becoming one of the most economically competitive forms of power generation (Exhibit 1.3). Technological progress has led to larger and more efficient turbines, and the everincreasing scale of manufacturing facilities has allowed suppliers to reap additional economies of scale. The entry of large incumbent firms from the electrical engineering sector, as well as new entrants from China, have further contributed to cost reductions. On the other hand, traditional sources of power generation have become more expensive due to carbon regulation and fuel price volatility. 


\section{Exhibit 1.3 Cost of generating electricity from coal, gas and wind power}

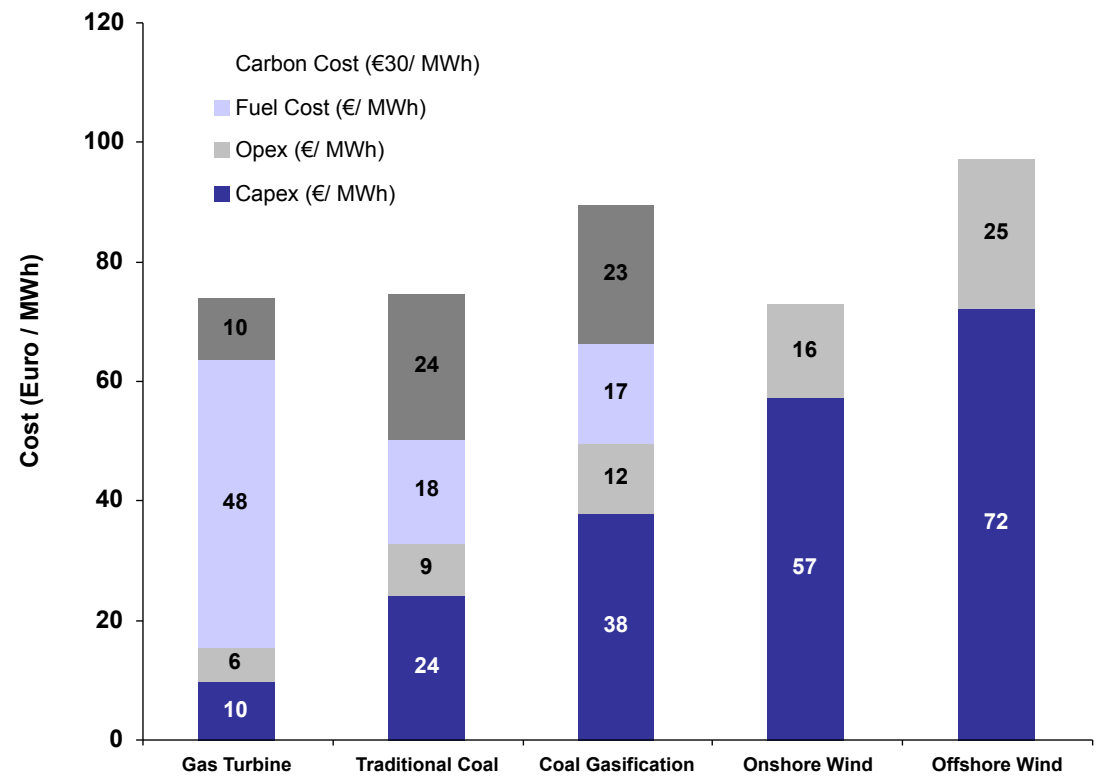

Source: EER (2007)

2008 marked yet another record year in the history of the wind energy sector. A total of 27,056 Megawatts (MW) of wind turbines were installed worldwide (see Table 1.1).

Table 1.1

Global Wind Market 2008 by Country

\begin{tabular}{l|l|l|l}
\hline Country & $\begin{array}{l}\text { Cumulative Capaci- } \\
\text { ty (MW) }\end{array}$ & $\begin{array}{l}\text { Newly Installed } \\
\text { Capacity (MW) }\end{array}$ & $\begin{array}{l}\text { Year-to-Year } \\
\text { Growth (2007-2008) }\end{array}$ \\
\hline U.S. & 25170 & 8358 & $49.7 \%$ \\
\hline Germany & 23903 & 1665 & $7.5 \%$ \\
\hline Spain & 16754 & 1609 & $10.6 \%$ \\
\hline China & 12210 & 6300 & $106.6 \%$ \\
\hline India & 9645 & 1800 & $22.9 \%$ \\
\hline Italy & 3736 & 1010 & $37.1 \%$ \\
\hline France & 3404 & 950 & $38.7 \%$ \\
\hline
\end{tabular}




\begin{tabular}{l|l|l|l}
\hline UK & 3241 & 836 & $34.8 \%$ \\
\hline Rest of the World & 22728 & 4528 & $24.9 \%$ \\
\hline Total & 120791 & 27056 & $28.9 \%$ \\
\hline
\end{tabular}

Source: GWEC (2009)

In Europe, in both 2008 and 2009, more wind energy was installed than any other source of electricity, including gas, coal and nuclear power plants (see Exhibit 1.4). Whereas politicians and industry associations in several countries adopted rhetoric of "nuclear renaissance", new nuclear capacity was limited to two reactors under construction in Finland and France in 2009, compared to 10,163 MW of new wind turbines in Europe alone.

\section{Exhibit 1.4 EU New Power Generation Capacity 2009}

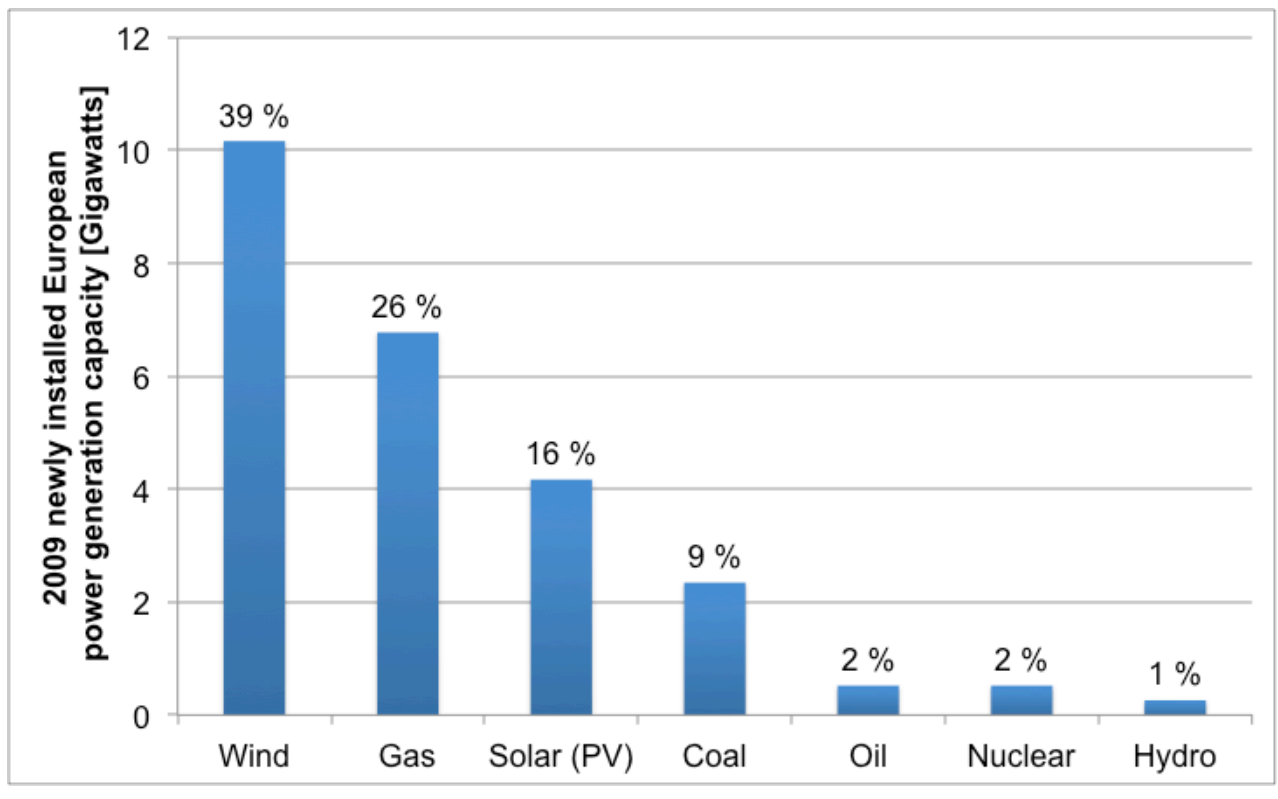

Source: European Wind Energy Association, Platts (2010)

Internationally, the U.S. and China were the top two countries in terms of newly installed wind turbines with 8,358 MW and 6,300 MW respectively. Germany now ranks second in terms of cumulative installed wind energy capacity $(23,903 \mathrm{MW})$ and gets $8 \%$ of its electricity from wind. Denmark continues to be the country with the highest share of wind energy in its national power supply (20\%). On windy winter nights, up to $100 \%$ of Danish electricity is generated by wind energy. The fluctuating nature of wind resources implies that wind 
power works best in a portfolio of different electricity sources. For example, countries with large capacities of hydropower storage plants like Switzerland or Austria are well positioned to supply energy-on-demand that complements the production characteristics of wind energy.

In Germany alone, the wind energy industry now accounts for over 96,000 direct jobs in wind power companies (BMU 2011), and further development of the renewable energy sector is seen as an important driver of economic growth. The installation of new wind turbines has also contributed significantly to the reduction of greenhouse gases. According to the European Renewable Energy Council, the wind turbines installed in Europe by the end of 2010 avoid the emission of 99 million tons of CO2 per year - equivalent to taking 50 million cars off the road, or about one quarter of the EU's obligation to reduce greenhouse gases under the Kyoto protocol (EREC 2004).

As this short snapshot shows, the global wind energy industry is a booming sector with an excellent growth outlook. At the same time, while a handful of European countries have achieved a significant penetration of wind energy in their power supply and others like the U.S. and China have started to catch up, the wind industry is still facing strong competition from dominant conventional players. Also, the concentration on a relatively small number of key markets and the strong influence of regulatory drivers implies a number of specific risks and opportunities. The next section provides a glance at market leader Vestas Wind Systems.

\subsection{Vestas Wind Systems: a Danish Niche Player's Journey to Global Leadership}

\section{8-1978: The Early Days of Vestas}

The roots of Vestas date back to the end of the $19^{\text {th }}$ century, when blacksmith H.S. Hansen opened his first workshop at Lem (Denmark). According to Vestas' history, Smith Hansen had a reputation for creating many ideas and showing fearless initiative, inspiring many of his colleagues at the time to start their own businesses and thus contributing to the emergence of an important center for the blacksmiths' craft at Lem. It was not until thirty years later that H.S. Hansen and his son, Peder Hansen, founded their first industrial company, Dansk Staalvindue Industri, a manufacturer of steel window frames for industrial buildings. After World War II, Peder Hansen formed a new company, Vestjysk Stålteknik A/S, which subsequently changed its name to Vestas. With starting capital of DKK 75,000, Vestas moved into the Business-to-Consumers (B2C) market of manufacturing household appliances and kitchens. Over the following 15 years (1945-1960), the company's product range continuously evolved, from appliances to agricultural trailers to intercoolers. In 1960, Vestas' offices and warehouse burnt to the ground and the factory had to be rebuilt. As a consequence, the company faced several years of consolidation, until it identified, in 1968, hydraulic cranes for light lorries as a new promising product area, which proved to be a major export success in a flourishing B2B market. A couple of years later, as the two oil crises of the 1970's hit the transportation industry and lorry crane, sales declined and Ves- 
tas had to look for yet another growth area.

\section{9-1985: First Steps in Wind Turbine Manufacturing}

Inspired by the second oil crisis in 1978-79, Vestas began to examine the potential of wind turbines as an alternative source of energy. Initially, they chose the Darrieus Turbine design, but after 18 months of experiments, the company decided to focus on a three-blade model, which soon became the dominant design in the wind industry. In 1979, the first wind turbines were delivered to Danish customers. Though being an industrial product, those deliveries were rather taking place in the B2C market, classically with medical doctors or other wealthy individuals enthusiastically investing in independent and environmental benign power production. Subsequently, the industry experienced its first boom, mainly driven by government incentives in Denmark and the United States, with Vestas definitely also entering a market driven by governmental incentives (B2G market). Vestas started serial production of $55 \mathrm{~kW}$ wind turbines in 1980. By 1985, the number of employees increased to 800. It was also in 1985 that Vestas introduced pitch-regulation, a major technological innovation that optimized the energy output of a wind turbine by constantly adjusting the angle of the blades to current wind conditions. By the end of that same year, Vestas had sold 2,500 wind turbines to the US.

\section{6: Crisis and Turnaround}

The strong exposure to the US market turned from blessing into curse for Vestas when at the end of 1985, the California tax credit legislation expired for the first time. As a consequence, Vestas' US market collapsed and, after a rescue plan failed, the entire company filed for bankruptcy in October 1986. This demonstrates that Vestas' characteristic ability to take advantage of growth opportunities wherever they emerged around the globe was not only a high-return, but also a high-risk, strategy. A more cautious approach to the booming California market might have mitigated downside risk, but would also have had limited upside potential if the tax legislation had in fact been extended. Another way of looking at this crisis is that Vestas apparently was better at managing technology risk than it was at managing regulatory risk. No governmental advisory services were then in place at the technology-focused company Vestas. On the positive side, there was a healthy core of the company that allowed for a major restructuring, which finally led to the establishment of a new company called Vestas Wind Systems A/S in 1987. After large parts of the Vestas Group had been sold off, the new company emerged as a wind energy pure player, managed by the new CEO Johannes Poulsen and with a dedicated team of 60 employees.

\section{7-2001: Strong Organic Growth and IPO}

It soon became apparent that the new Vestas was set to become a unique success story. The years 1987 to 1997 saw a sequence of international expansion, technological innovation and ever larger orders. The company set up subsidiaries in India (1987), Germany (1989), Sweden, and the US (both in 1992), and formed the joint-venture Gamesa Eolica in Spain (1994), where Vestas held $40 \%$ of the shares and Gamesa, the parent company, 51\%. The Spanish 
market became a particularly important market in the mid-1990s, when big utilities started placing large orders to benefit from government incentives. In terms of technology, Vestas as did its very first competitors - gradually increased turbine size with every new generation of their product. While the company had entered the wind turbine business with a 55 $\mathrm{kW}$ machine back in 1980, it introduced its V39-500 kW turbine in 1990, followed by the V44-600 kW turbine in 1994 and the V66-1.65 MW turbine in 1997. Today, the company offers a V52-800 kW, the V60-800 kW for the Chinese market, the V80-1.6 / 1.8 MW for the US market, the most successful V90-2 MW for the global market, the V90-3 MW for stronger and offshore wind sites, as well as a V100-3 MW and its new V112-3 MW for low wind sites especially in maturing markets.

Most of Vestas' exceptional growth during this period (see Exhibit 1.5) was organic, accelerated with only selected acquisitions as in the case of DWT - Danish Wind Technology in 1989 or Costas Computer Technology A/S, a long-standing supplier of software and components for Vestas' wind turbine control systems, which was taken over in 1999. When expanding into new international markets, the company often chose to form a joint-venture together with a well-established partner in the target country, as was the case with Vestas RRB India Ltd. or the joint-venture with Energy System Taranto S.p.a. in Italy. In countries where Vestas felt comfortable that they knew the market, however, they went in with fully owned subsidiaries, as in the cases of the US, Sweden and Germany.

This decade also saw Vestas' first turbine deliveries to a smaller offshore project, involving ten $500 \mathrm{~kW}$ turbines in the Baltic sea in 1995. Also in 1995, the company for the first time exceeded 1,000 employees and generated more than 200 mio $€^{1}$ of revenues, a $66 \%$ growth rate over the previous year. It became increasingly clear that in order to maintain the pace of growth, the company needed additional sources of capital. Two years later, in 1997, the company introduced two new turbine models and consequently posted a slight loss, despite sales growth (in MW) of $24 \%$. Therefore, in early 1998, CEO Johannes Poulsen announced that the time had come to float the company on the Copenhagen Stock Exchange, stating that in his opinion, "there is no doubt that in future environmental factors will play an increasingly large role in any political and probably also any commercial decision" (Press release announcing IPO, March 23, 1998).

\footnotetext{
${ }^{1}$ For convenience, all financial figures in this paper have been converted from Danish crowns to euros with the exchange rate of July 2009 (1 DKK = 0.134 EUR).
} 


\section{Exhibit 1.5 Profits (EBIT), Revenues and Employees at Vestas 1994-2008}

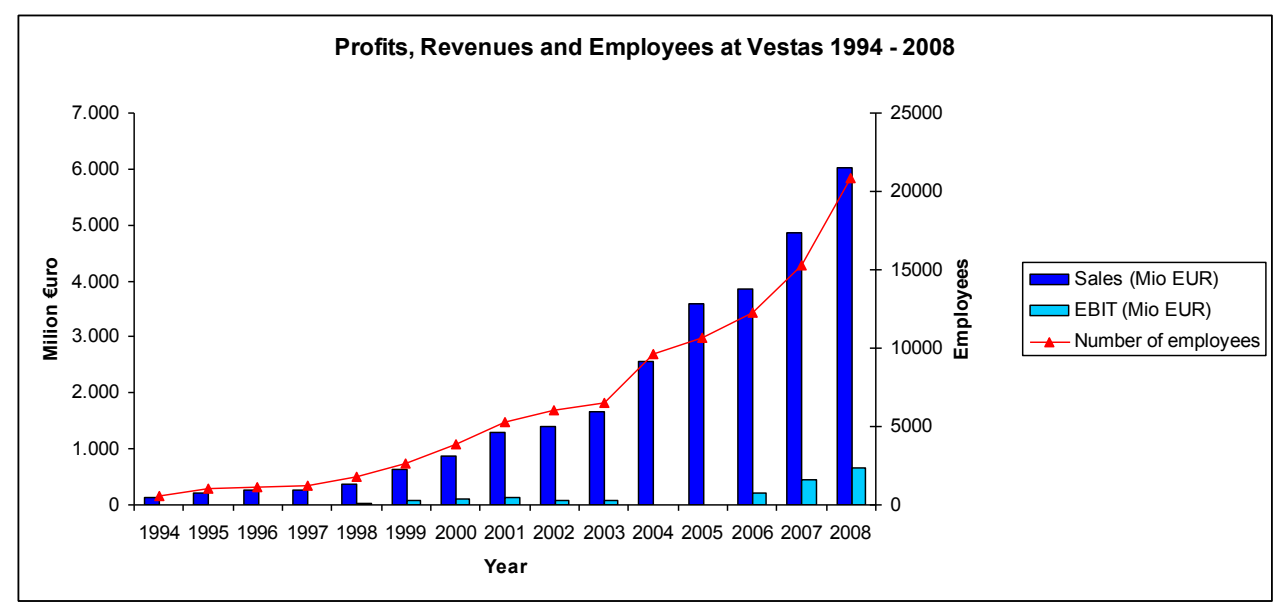

Source: Vestas Annual Reports (1994-2008)

Vestas' initial public offering in April 1998 became a big success. The shares were eight times oversubscribed and the company raised 175 million euros of fresh equity capital to finance its future growth, including new international subsidiaries and new fiberglass production and turbine assembly facilities. During the year of its IPO, Vestas increased revenues by $45 \%$ and opened production in the newly established Italian joint-venture in July 1998. Within its first year, the Italian subsidiary immediately generated revenues of 35 million euros with just 50 employees. 1999 saw the opening of a new blade factory in SouthEastern Denmark, an area of high unemployment that provided good recruiting opportunities for Vestas, as well as the launch of a prototype V80-2.0 MW turbine. 1999 became another record year for Vestas, largely due to exceptional growth in the US market. At the end of 1999, the Production Tax Credit (PTC) expired, an important financial incentive to wind energy generators in the US. Thus, a large number of project developers ordered turbines before the end of the year to take advantage of the incentive. As a result, Vestas increased sales by $66 \%$ and more than doubled profits compared to the previous year. In 2000, growth continued, fuelled among other things by the largest order ever for wind turbines, received by Vestas' Spanish joint-venture Gamesa from Energia Hidroeléctrica De Navarra, worth more than 600 million euros.

2001 brought more good news for Vestas, being chosen as the supplier for the first major offshore project in the North Sea (Horns Reef), which meant the largest offshore order to date, worth around 130 million euros. 2001 was also the year with the strongest growth of the global wind energy market in history, increasing by $51 \%$ over 2000 levels. In this year, Vestas achieved a market share of $24.1 \%$ and was clearly the market leader. However, 2001 can also be seen as a turning point in Vestas' history in several respects. Remarkably on the 
morning of September 11, 2001, the company announced that 59-year old CEO Johannes Poulsen, who had led the company since it was formed in 1987, had decided to resign from his position at the General Meeting in April 2002.

Also, increasing strategic differences between Vestas and Gamesa led to the sale of Vestas' $40 \%$ stake in the joint-venture in December 2001. Retrospectively, Vestas had ultimately helped to grow a major competitor who was now seeking independence. Finally, the outlook for the US market appeared uncertain following another expiration of the PTC. Due to different political priorities in the aftermath of the September 11 terrorist attacks and contentious issues in the proposed US energy bill, PTC extension was eventually delayed until March 2002. The company ended the year 2001 with 5,240 employees, which meant a tripling in the three years since the IPO.

\section{2-2004: Changing of the Guard and the Merger with NEG Micon}

The beginning of the post-Poulsen area at Vestas was challenging in many ways. The start of Svend Sigaard, the former CFO and new CEO, was accompanied by the news that a major competitor entered the market: General Electric (GE). The large US engineering conglomerate announced in February 2002 that they had acquired the assets of Enron Wind from the bankruptcy proceedings of Enron and formed a new subsidiary, GE Wind. As an established player acknowledging the growth potential in the wind energy market, this news was perceived as a boost to the credibility of the emerging industry. Given GE's influential position in the US, it may also not be fully accidental that legislation extending the PTC was passed only five weeks after they had announced their market entry. Nevertheless, given GE's expertise in the conventional power business, its strong distribution channels in North America, and its financial strength, this clearly became an important new competitive threat for Vestas. In addition, during 2002, Vestas struggled with technical problems on its new flagship V80-2.0 MW turbine and faced delays at the high-profile Horns Reef offshore project, which eventually resulted in cost overruns of 15-17 million euros. Looking positively at this, Vestas had an opportunity to learn important lessons for the emerging growth market of offshore wind parks. In contrast to the previous boom years, 2002 ended with the company's announcement that after the second profit warning in three months, they had to lay off 495 employees - the first downsizing since 1986.

In 2003, Vestas introduces its new flagship turbine V-90 $3 \mathrm{MW}$, which made wind power technology even more competitive and still is a standard product in today's market. In order to step up to increasing competition, Vestas and its Danish competitor NEG Micon merged in 2004; this represented a combined world market share of $32 \%$, which was even increased to $34 \%$ by the end of the year. In the same year, CEO Svend Sigaard resigned.

\section{5-2008: The "Will to Win" leading to record results in turbulent times}

In 2005, new CEO Ditlev Engel introduced Vestas' "Will to Win" strategy with the objective of making wind a competitive source of power on par with oil and gas. Ditlev Engel formerly worked with Danish protective paint producer Hempel A/S, and his journey at Vestas did not start as a walk in the park - high steel prices combined with a weak US dollar 
squeezed Vestas' margins and started to severely hit its profitability. However, the PTC in the US became effective again and led to Vestas' biggest order intake so far from Horizon Wind Energy in the US. 2006 marked the opening of Vestas' production facilities in Tianjn, China. Financially, Vestas still lost money primarily due to high repair costs. However, the "Will to Win" strategy led to a profitable 2007. Vestas' financially best year ever was 2008, when operating profits increased by more than $50 \%$ year-on-year to reach 668 million euros, an increase in employment of 5,524 new employees and an EBIT margin of $11.1 \%$. While Vestas was successful in maintaining higher profitability than many of its competitors, including GE Energy, it lost some market share in 2008. Vestas accounted for about $19 \%$ of the global wind turbine sales, with the decline being mainly due to recent entrances and growth of new competitors in China, India and the US. In China, Sinovel and Goldwind accounted for the majority of order intakes and - although exclusively delivering to China - for $9 \%$ of global sales (in MW). Indian Suzlon exporting to the world market accounted for another $9 \%$ of global MW sales. And GE Wind's aggressive sales strategy in the US as part of its "Ecomagination" program led to a global market share almost on par with wind-focused Vestas (see Table 1.2).

Table 1.2 Market share of wind turbine manufacturers as of 31/12/2009

\begin{tabular}{|c|c|c|c|c|c|c|c|}
\hline No & Name & Location & $\mathrm{P} / \mathrm{S}^{*}$ & $\begin{array}{l}\text { Tur- } \\
\text { bine } \\
\text { sales } \\
\text { in } \\
2009 \\
\text { [MW] }\end{array}$ & $\begin{array}{l}\text { Market } \\
\text { share } \\
2009 \\
{[\%]}\end{array}$ & $\begin{array}{l}\text { Cumula- } \\
\text { tive sales } \\
\text { since } \\
\text { market } \\
\text { entry } \\
{[\mathrm{MW}]}\end{array}$ & $\begin{array}{l}\text { Market } \\
\text { share } \\
\text { cumul. } \\
{[\%]}\end{array}$ \\
\hline 1 & Vestas & Denmark & $\mathrm{P}$ & 4766 & $12.5 \%$ & 39705 & $24.8 \%$ \\
\hline 2 & GE Wind & USA & $S$ & 4741 & $12.4 \%$ & 22961 & $14.3 \%$ \\
\hline 3 & Sinovel & China & $\mathrm{P}$ & 3510 & $9.2 \%$ & 5658 & $3.5 \%$ \\
\hline 4 & Enercon & Germany & $\mathrm{P}$ & 3221 & $8.5 \%$ & 19798 & $12.4 \%$ \\
\hline 5 & Goldwind & China & $\mathrm{P}$ & 2727 & $7.2 \%$ & 5315 & $3.3 \%$ \\
\hline 6 & Gamesa & Spain & $P$ & 2546 & $6.7 \%$ & 19225 & $12.0 \%$ \\
\hline 7 & Dongfang & China & $\mathrm{P}$ & 2475 & $6.5 \%$ & 3765 & $2.4 \%$ \\
\hline 8 & Suzlon & India & $\mathrm{P}$ & 2421 & $6.4 \%$ & 9671 & $6.0 \%$ \\
\hline 9 & Siemens & Germany & $S$ & 2265 & $5.9 \%$ & 11213 & $7.0 \%$ \\
\hline 10 & Repower & Germany & $\mathrm{P}$ & 1297 & $3.4 \%$ & 4894 & $3.1 \%$ \\
\hline 11 & Nordex & Germany & $\mathrm{P}$ & 1060 & $2.8 \%$ & 6105 & $3.8 \%$ \\
\hline 12 & $\begin{array}{l}\text { United } \\
\text { Power }\end{array}$ & China & $\mathrm{P}$ & 768 & $2.0 \%$ & 792 & $0.5 \%$ \\
\hline
\end{tabular}




\begin{tabular}{r|l|l|l|r|r|r|r}
\hline 13 & Clipper & USA & $\mathrm{P}$ & 595 & $1.6 \%$ & 898 & $0.6 \%$ \\
\hline 14 & Mitsubishi & Japan & $\mathrm{S}$ & 583 & $1.5 \%$ & 3252 & $2.0 \%$ \\
\hline 15 & Mingyang & China & $\mathrm{P}$ & 573 & $1.5 \%$ & 747 & $0.5 \%$ \\
\hline
\end{tabular}

${ }^{*} \mathrm{P}=$ Pure Play, $\mathrm{S}=$ Subsidiary

Source: BTM Consult (2010)

Vestas' success in the period 2005-2008 is reflected in a more than six fold increase in its share price, from less than 100 DKK in the beginning of 2005 to an all-time-high of 692 DKK at the end of August 2008, two weeks before the collapse of Lehman Brothers marked a milestone in the global financial crisis (see Exhibit 1.6).

\section{Exhibit 1.6 Vestas Share Price 2005 - 2009}

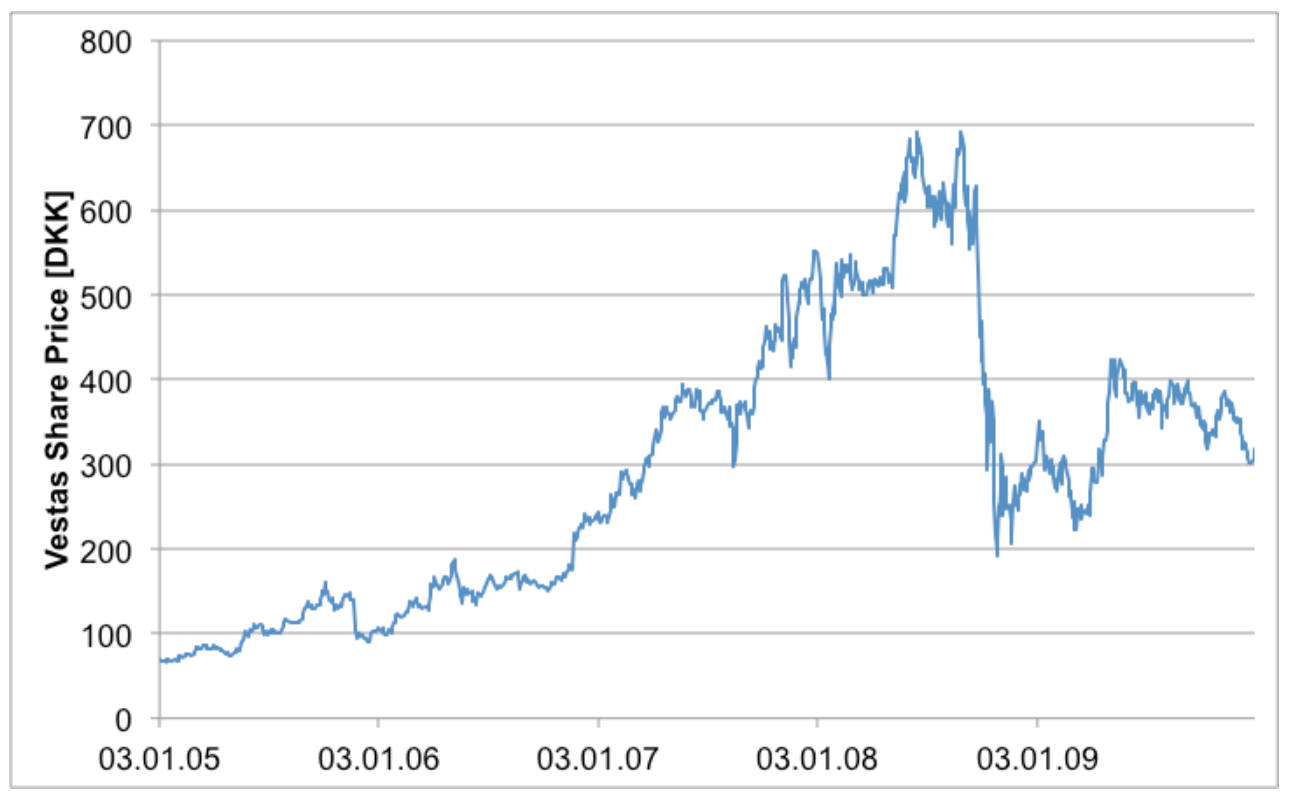

Shareprice Data: euroinvestor.com (2011)

\subsection{Opportunities and Challenges in Remaining "No. 1 in Modern Energy"}

Ever since it has been exclusively focused on wind energy in 1987, Vestas has been leading 
the wind turbine manufacturing industry in terms of market share. Being "No. 1 in Modern Energy", as CEO Ditlev Engel puts it (Engel 2008), has not been an easy task, and remaining so in an increasingly competitive industry will lead to a number of further challenges.

\section{Managing Internal Growth}

Not only has Vestas grown from 1,000 to over 20,000 employees in less than 20 years (Exhibit 1.5), but it also operates in a market where annual growth rates of $25-30 \%$ have been the rule rather than the exception for the same period. Given the favorable outlook for the wind market, the company expects to grow by an annual rate of $33 \%$ in the next three years, doubling its turbine output from 5,000 MW in 2007 to 10,000 MW in 2010. "This is more than a gigantic challenge", says CEO Ditlev Engel, adding that "change is never easy, but when, at the same time, you are talking about developing a new form of energy at global level, it is almost as difficult as it gets." Even for a company that has an impressive track record of managing internal growth, the dynamics of this industry represent a recurring challenge, but also amazing opportunities.

\section{Increasing Competition}

While Vestas operated in a sellers' market for more than a decade, large incumbent players have started to enter the field since 2002, making it more important for Vestas to position itself as a preferred provider of wind power solutions. GE, under its "ecomagination" campaign, launched an aggressive campaign to position itself in the green energy market. Not only marketing budgets were increased, but real efforts were put into a transformation of the company's product portfolio and revenue streams. Between 2005 and 2008, GE increased its eco-efficient portfolio from 17 to 80 products, increased R\&D investments for environmental energy solutions from $750 \mathrm{mn}$ to $1.4 \mathrm{bn}$ USD and boosted its revenue with ecomagination products from 10 bn to 17 bn USD (GE, 2008). On the wind turbine product side, GE now positions itself as a premium supplier of grid-friendly wind power solutions, pointing at decades of experience with various energy solutions for stable energy supply. Last but not least, GE's financial services arm allowed the firm to offer financial solutions to customers seeing wind-financing banks drawing back from unsecure markets and requiring larger shares of equity in wind projects. 


\section{Exhibit 1.7 Market entry timing of Vestas versus large incumbent firms in global wind energy industry}

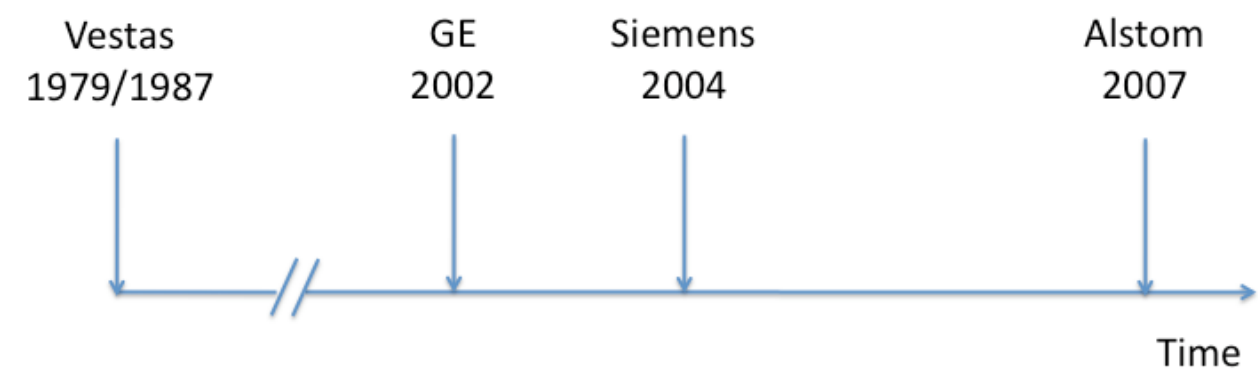

Source: own compilation

While it took GE's close competitors a while to react (see Exhibit 1.7), Siemens was the second major entity to enter the field two years later by acquiring Bonus, a Danish manufacturer of wind turbines. Today, the company holds a global market share of $7 \%$. Including other technologies like fuel cells and waste-to-energy plant, the company reports 2008 revenues of 27 bn USD with its environmental portfolio. Like GE, Siemens' strong position in energy financial services gives it an advantage over a pure player like Vestas in times of the credit crunch. The firm's financial services arm is said to have supported major sales contracts in the turbulent 2009 market - amongst others with major Danish utility DONG, signing a framework agreement for 500 Siemens offshore wind turbines for the client's offshore projects in Northern Europe.

Increasing competition is also coming from China, where Goldwind, Sinovel and Dongfang are now among the top 12 producers of wind turbines worldwide, and 35 new manufacturers have entered the market in 2008 alone. Vestas continues to be the largest foreign turbine manufacturer in China, with facilities in Beijing and Tianjin, and recent investments in new production facilities in China's wind-rich industry hub Hohhot.

David vs. Goliath - the pros and cons of being a pure player

A much smaller player than Siemens and GE, Vestas had a product portfolio of five Wind Turbine Generators, R\&D costs amounted to $170 \mathrm{mn}$ USD and achieved revenue was $8.5 \mathrm{bn}$ USD in 2008. Unlike those larger players, Vestas is not equipped for major lending to its customers, a disadvantage during the financial crisis where banks have become extremely risk-averse and do no longer lend up to $75 \%$ of a project's cost, despite the proven technology and often guaranteed long-term returns of those projects due to established government policies. With their extensive conventional power technology business and established relationships in B2B markets, GE and Siemens have a far stronger foothold among electric utilities and grid operators than Vestas. This is an important factor in a market 
where the customer base is increasingly shifting towards larger clients. With a base of several hundred customers, Vestas finds itself still serving a relatively large number of small wind energy project developers, while large utilities such as the world's largest wind power producer Iberdrola, Portuguese EDP, Spanish Acciona Energia and Endesa, Chinese Longyuan, German E.ON, French EDF-EN, US MidAmerican, or Independent Power Producers like US NextEra Energy Resources or Chinese Datang increased their holdings of wind power solutions to now form a group of the 10 largest wind power producers globally (EER, 2009). Some of them started to build up their own development departments or sub-companies. Not least during the financial crisis, utilities with relatively large financial means and modest interest requirements find themselves more capable of finalizing wind projects through increased balance sheet financing with at least $50 \%$ equity.

On the other hand, almost like a David among Goliaths (Hockerts and Wüstenhagen 2011), Vestas' focused position and smaller size also have important advantages. When it comes to being an early player in new markets, Vestas has developed unique capabilities in its 20 plus years of being a $100 \%$ wind-focused company. It is the most internationally diversified, focused wind turbine producer and marketer with global exposure (see Exhibit 1.8). Vestas' wind market know-how on practically every wind market in the world remains unmatched. This puts Vestas in a good position to profit from global markets wherever they were. When one market became too saturated and price-competition too fierce, Vestas was and is still able to sell where conditions are more favorable. And looking at the global market as a whole, the wind market has probably been one of the most attractive markets in recent economic history with growth-rates comparable to those in the emergence of IT markets.

Exhibit $\mathbf{1 . 8}$ Vestas' global revenue distribution

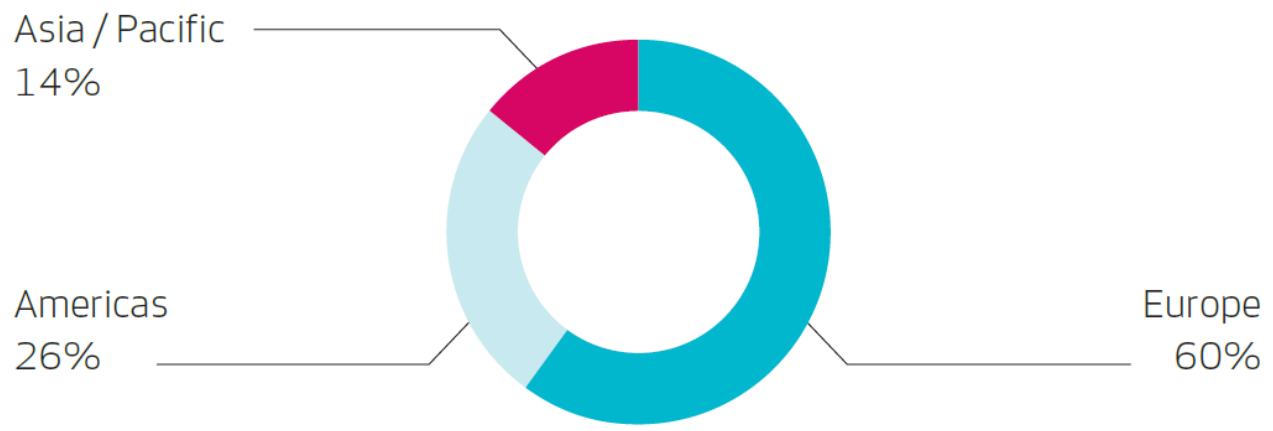

Source: Vestas Annual Report (2008)

On the customer side, more and more utilities and experienced wind park developers are 
starting to look for new opportunities in emerging markets. While it was hard for some to take their suppliers of wind equipment off to new markets, Vestas is present in almost all markets where turbines were sold so far either through local offices and production or through local or nearby service staff. Its historic first-mover advantage in many emerging markets especially in Eastern Europe, Asia and Middle East differentiates Vestas from most competitors and puts it into a favorable position as a supplier to increasingly internationalizing customers.

\section{Exhibit $\mathbf{1 . 9}$ Vestas' $100 \%$ wind-focused value chain}

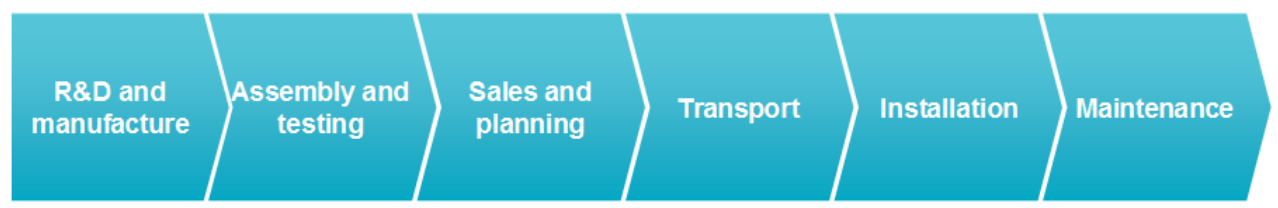

Source: Company Data

Vestas' complete focus on wind power, or "modern energy" as the company calls it, not only makes it the most experienced player in the field with unmatched know-how about the global wind business, but also allows it to invest in its business without making compromises. Large incumbent players entering the wind industry, in contrast, may find themselves in the midst of internal and external controversy between "new" and "old" business, where existing customers push back against a focus on renewables. Jeff Immelt, the CEO of GE, pointed out that introducing the "Ecomagination" strategy was not easy to do for exactly those reasons: "There were plenty of guys on our energy team who hated this in the beginning because half of their customers were saying they hated it" (Stewart 2006). Immelt explains that he managed to convince the skeptics by outlining the long-term objectives behind Ecomagination and presenting it as making pure business sense: "We just kept talking: 'Here's where we're going. Here's why we think it's good for both of us. And it's going to come someday anyhow, so let's get ahead of it'" (ibid). And although Ecomagination's sales numbers today provide evidence that customers liked the products even more than expected, large players such as GE and Siemens still also serve clients whose core business is in the coal or nuclear business, sometimes perceiving wind as too junior and an inconvenient form of power production.

\section{Managing risk \& opportunity of a "political climate that has never been better"}

As quoted in the introduction, Vestas CEO Ditlev Engel pointed out at the 2008 earnings presentation in spring 2009 that "the political climate has never been better". Awareness for the environmental, economic and social challenges as a result of global warming, the issue of energy security in the light of scarce resources and increasing demand from emerging countries as well as the quest for identifying opportunities to create "green jobs" have cre- 
ated significant momentum in the international policy arena that can work to the advantage of renewable energies. Wind energy, as the most mature renewable energy source available (apart from hydropower), is set to benefit. However, as Vestas has experienced several times throughout its history, the flipside of a positive political climate is regulatory risk, which in fact drove the company's predecessor into bankruptcy in 1986. Energy policy can hence be a double-edged sword for Vestas, and the inherent risks require to be well managed.

On the opportunity side, there are a number of positive developments on global, European, national and state levels that Vestas and its peers can benefit from. The United Nations Framework Convention on Climate Change (UNFCCC) aims at significant reductions of greenhouse gases on a global level, and despite the fact that reaching global consensus is no easy task, there is an increasing awareness which will eventually result in stricter regulation of greenhouse gases, shifting the rules of the game in favor of wind energy and other low-carbon energy technologies. At least equally significant are policies on regional and national levels, such as feed-in tariffs for wind energy in several European countries, production tax credits in the US and renewable portfolio standards (RPS) in many US states which mandate utilities to provide a minimum share of renewables.

A more recent opportunity results from attempts by governments to stimulate their ailing economies. Experts like former World Bank Chief Economist Sir Nicholas Stern, now at the London School of Economics, have pointed out that such stimulus packages should be addressed as "green growth", in order to address the financial crisis and the climate crisis simultaneously. As Exhibit 1.10 illustrates, a number of countries follow that advice, notably South Korea, the European Union and China, with substantial shares of green investments in their stimulus packages. The graph also demonstrates, however, that many countries seem to set other priorities and invest in areas like building highways and subsidizing the construction sector. An interesting case is represented by the United States, where only about $20 \%$ of the stimulus package is dedicated to renewable energy and other green measures, but in the light of the vast size of that package, this still represents a major opportunity. From the perspective of a wind turbine manufacturer, this may be one of the factors to consider in planning their internationalization strategy. 


\section{Exhibit 1.10 Share of environmental measures in stimulus packages of 10 countries and the EU}

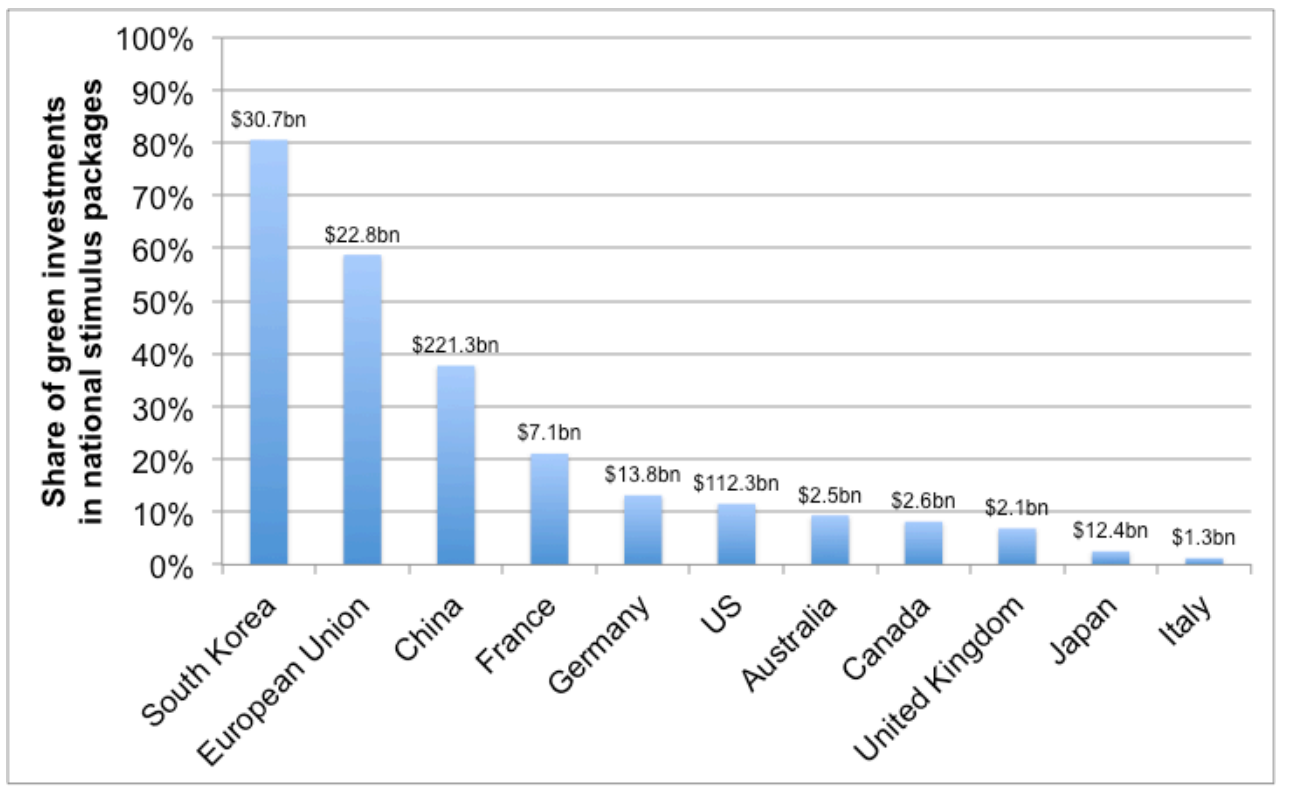

Source: HSBC (2009)

While policy can hence be an important driver for wind energy, it also involved substantial risks. A particular challenge is policy uncertainty. Two kinds of uncertainty are particularly relevant to the wind energy market, namely the price volatility inherent in some types of policies to promote renewable energy, and the risks of stop-and-go policies.

As for price volatility, a notable example is Italy, where power producers in 2008 either had to produce $5 \%$ of their energy portfolio by renewable energies or set their requirements off by purchasing green certificates. In Italy alone, certificate prices in 2008 varied by some $46 \%$ between $9.5-5.4 €$ cents / certificate in addition to volatile wholesale electricity prices, leaving investors with significant uncertainty about their business case. Although not strictly policy-related, the volatility of oil and gas prices also has an effect on the economic viability of wind energy investments. The strong decrease in oil and gas prices since late 2008 has shifted the balance between conventional power plants and wind turbines. On the other hand, investors may also see the lower volatility of wind power prices as a hedge against fuel price risk. In terms of policies, the so-called feed-in tariff, which was introduced in Germany in 1991 and has been applied in many other countries more recently, has proven to be an effective measure to reduce investment risk. Under this policy scheme, the operator of a wind turbine gets guaranteed returns for a long period of time (usually 20 years). 
While feed-in tariffs have been criticized for being overly generous to renewable energy producers in some countries, they have clearly been the most effective policy in terms of stimulating renewable energy investment and capacity additions, hence helping governments to reach their renewable energy and climate policy targets.

The other kind of policy uncertainty is related to stop-and-go policies. Unfortunately, policies in many countries have been subject to frequent changes, the prime example being the US where tax incentives for wind energy have gone through cycles of being introduced, expired, re-introduced, and so forth. This has led to a boom-bust-cycle in wind energy investment, and therefore industry associations and environmental groups are lobbying for a longer-term perspective. The fact that one of the largest companies in the US, GE, is also on the side of potential beneficiaries of such an increased policy certainty has probably not reduced the chances of getting this into place.

\section{Exhibit 1.11 New installation of wind power capacity in MW during years with production tax credit and without}

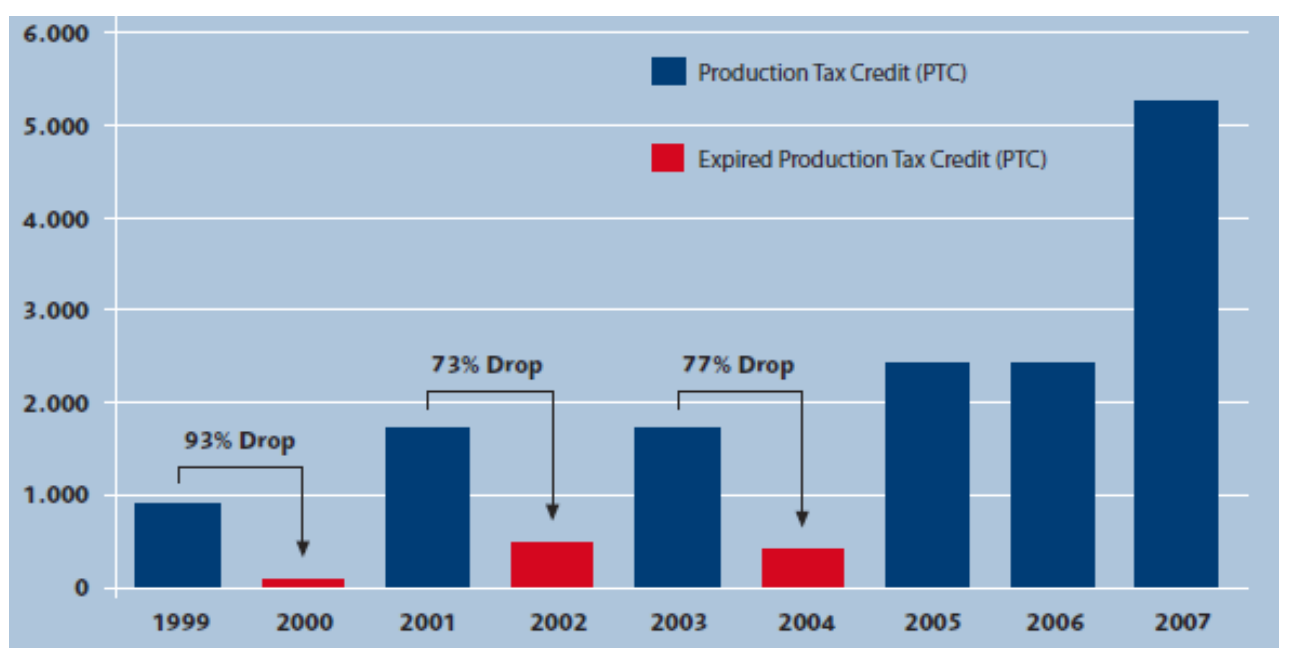

Source: AWEA (2009)

\subsection{Outlook}

With more than $80 \%$ of the world's economy currently depending on non-renewable sources of energy, the need to cut carbon emissions by $80 \%$ by 2050 , and wind energy being one of the most cost-competitive sources of clean energy today, there is little doubt that the wind turbine industry is set for a continuation of its tremendous growth path for decades to come. The recent market entry of large manufacturing firms like GE, Siemens, Alstom and Areva, the increasing exposure of incumbent energy utilities like EDP, E.On, Vattenfall, 
EDF and Endesa, but also the entry of financial services firms like Allianz, Goldman Sachs and Blackstone into this sector indicates that wind energy has made a lot of progress on its way from niche to mainstream market. From humble beginnings in the 1980s, Vestas has consistently grown with the industry over more than two decades and is still the market leader. The competitive challenges facing the company are substantial, but so are the market opportunities. The future will tell how big of a slice of the pie Vestas will continue to be able to claim for itself. Given its strong internationalization capabilities, its consistent focus on profitability and its track record of managing internal growth, the company seems well positioned to ride the wave of opportunity. As CEO Ditlev Engel puts it: "Taking the lead demands that we have the courage to change and adapt while things are going well. (...) After all, it is most fun to stand on top of the winner's podium. And quite honestly, why in the world should Vestas not stay there?"

\section{Student Assignments}

\section{David vs. Goliath - the pros and cons of being a pure player}

1. Consider the situation when GE entered the wind industry in 2002 as the first large incumbent player: What were the main opportunities and challenges arising for Vestas, and for the wind turbine industry as a whole?

2. As you saw from Exhibit 1.7, some of the large incumbent players took much more time to enter the wind energy industry than others. What might explain these differences in market entry timing?

3. What are the pros and cons of being a pure wind energy player at the current stage of industry development? How could Vestas make best use of its advantages, and how could it hedge against its disadvantages as a pure player? How does the financial crisis influence your assessment?

\section{Business-to-Government (B2G) - managing policy risk (and opportunity)}

4. How has energy policy influenced Vestas' corporate strategy in different stages of its history from 1985 to today?

5. What are the differences between the 1986 crisis and the company's current position? What are some commonalities?

6. Global climate policy, economic stimulus packages and national renewable energy legislation are three examples of policies that Vestas could benefit from in the near future. How could the company - either on its own, or together with other players in the industry - try to influence adoption of such policies? Which of those options would you recommend the company to prioritize? 


\section{References}

[1] BMU 2011. Bruttobeschäftigung durch erneuerbare Energien in Deutschland im Jahr 2010 - eine erste Abschätzung. Stand: 18. März 2011. Berlin: Bundesumweltministerium.

[2] BTM Consult 2010. World Market Update 2009. Ringkøbing: BTM Consult. March 2010.

[3] EER 2007. Comparative Costs of Energy. Europe 2007 Update. Cambridge/Barcelona: Emerging Energy Research., 15 October 2007.

[4] Engel, D. 2008. Remaining No. 1 in Modern Energy is not a given. Vestas Inside, Issue 4, pp. 8-11.

[5] EREC 2004. Renewable Energy. The solution to climate change. Brussels: European Renewable Energy Council.

[6] GWEC 2009. Global Installed Wind Power Capacity - Regional Distribution. Brussels: Global Wind Energy Council.

[7] GWEC 2011. Global Wind Statistics 2010. Brussels: Global Wind Energy Council.

[8] Hockerts, K. and Wüstenhagen, R. (2010): Greening Goliaths versus Emerging Davids - Theorizing about the Role of Incumbents and New Entrants in Sustainable Entrepreneurship. Journal of Business Venturing, 25 (5), 481-492.

[9] HSBC 2009. A Climate for Recovery: The colour of stimulus goes green. London: HSBC Global Research, 25 February 2009.

[10] IPCC 2007: Climate Change 2007: Synthesis Report, Cambridge/New York: Cambridge University Press.

[11] IPCC 2011: Special Report on Renewable Energy Sources and Climate Change Mitigation Summary for Policy Makers. Cambridge/New York: Cambridge University Press.

\section{Acknowledgements}

The author would like to thank Gian Schelling, who after graduating with a CEMS Master in International Management (CEMS-MIM) joined the Vestas graduate program and now works in Group Marketing \& Customer Insight at Vestas, for his valuable support in data collection and preparation of an earlier draft of this chapter. Parts of section 1.2 of this chapter build on an earlier case study published as: Wüstenhagen, R.: Sustainability and Competitiveness in the Renewable Energy Sector: The Case of Vestas Wind Systems, Greener Management International, No. 44 (Winter 2003), pp. 105-115. Any remaining errors are the sole responsibility of the author. 